\title{
ANTROPOLOGIA JURÍDICA
}

\author{
LFGAI. ANTHROPOLOGY
}

Fabiuno Yuji Takayanagi

\begin{abstract}
Resumo:
O objetivo desta pesquisa é analisar a evolução do homem, um "animal politico" segundo definição de Aristóteles, desde seu periodo primitivo e solitário até a formação das grandes civilizações chegando em seu grau máximo de organização social. o Estado. Além disso, poderemos nos aprofundar. após definir a finalidade do Estado. sobre questões como sua real efetividade, para com sua população, quando surgem os Estados Paralelos e ainda questionar a necessidade de um Estado para conduzir uma civilização sendo que ainda existem povos sem tal aparato de organização social.
\end{abstract}

Palavras-chave: Antropologia. Origem da sociedade. Origem e formação do Estado. Finalidade do Estado. Estado paralelo.

\begin{abstract}
:
The aim of this research is an analysis of the men s evolution, a "political animal" according to Aristoteles, since their solitary and primitive period to the lormation of the largest civilizations, reaching their maximum grade of social organization. the State. Moreover, after defining the finality of State. we go deep on questions like the real efectivity of State for the population when appear the Parallel States and yet to question the necessity of a State to lead a civilization, although there are peoples without the support of social organization.
\end{abstract}

Keywords: Antropology. Origin of society. Origin and formation of State. Finality of State. Paralell State.

\section{Introdução}

Antropologia é o estudo do homem e dos grupos humanos. Podemos também definir como teoria filosófica que tem o homem como centro de suas preocupações. Esse estudo possibilitou a ramificação da Antropologia que pode ser verificado na Antropologia cultural ou social, estudo das crenças e das instituições de um grupo. concebidas como fundamento das estruturas sociais e consideradas em suas relações com a personalidade; Antropologia econômica, análise teórica comparada de diferentes sistemas econômicos; Antropologia politica, estudo das instituições e do funcionamento do poder política nas sociedades: Antropologia religiosa, estudo sistemático de um grupo social analisando em função de suas crenças coletivas e de seus

Aluno do Curso de Graduaçào da Faculdade de Direito da L'niversidade de São Paulo. 
ritos; e finalmente a Antropologia jurídica que estuda as relações interpessoais de um determinado sistema político seja estruturado pela religião, seja embasado por outro tipo de influência ou dominação, incluso num determinado sistema econômico.

O estudo de Antropologia necessita da História, Arqueologia, Sociologia entre outras disciplinas científicas para que possamos presumir o início das relações humanas e suas causas. Esse entrelaçamento entre disciplinas ainda não é suficiente para montarmos uma teoria concisa e única para a formação da sociedade e seus Estados, ou seja, suas relações político-sociais.

Sendo assim, tenho por objetivo analisar as sociedades desde os tempos passados até o presente a fim de, através da Antropologia, compreender o objeto focado nesse trabalho que é a formação do Estado e as organizações sociais que existem sem a sua presença.

A vida em grupo

2. A História

Fósseis de ancestrais humanos revelam seus primeiros indícios de bipedalismo na África há 4 milhões de anos e os hábitos alimentares, caça de animais selvagens de grande porte evidenciam a necessidade de agrupamentos para o abate, logo percebe-se uma certa necessidade de formação de bandos para tal fim. Ossadas fossilizadas indicam o aperfeiçoamento da estrutura corpórea dos nossos ancestrais como mandíbulas mais fortes, corpos mais eretos e equilibrados, além disso, foram descobertos instrumentos de caça; o que justifica a evolução desse animal para adaptação ao meio em que viviam.

As inovações feitas pelos ancestrais do homem levaram-no ao aperfeiçoamento de técnicas de caça com uso de ferramentas cortantes e o uso do abrigo para proteção permitiu-lhe maior resistência contra o frio e predadores. Era a época do Paleolítico. No entanto, foi por volta de 10 mil a.C., período do Neolitico, que houve uma revolução estrutural na linha de evolução humana de maneira definitiva e inovadora, surge a agricultura; após o degelo da Era Glacial.

Essa mudança é considerada crucial para a evolução humana, porque o cultivo da terra fixou o homem a ela, ele se tomou um animal sedentário e não-só um nômade dependente da caça e coleta de alimentos. As comunidades humanas realizavam atividades diferenciadas impulsionando ao crescimento populacional, pois a garantia de alimentos diminuía o número de mortes. As conseqüências para isso são: a criação de excedentes, o surgimento de propriedades juntamente com atividades comerciais, o 
aparecimento de cidades primitivas e as primeiras formas de organização estatal para, por exemplo, organizar a comunidade, administrar os excedentes, a defesa contra outros povos. Essa união de fatores e conseqüências deram origem às grandes civilizações.

As principais características das grandes civilizações orientais como as que povoaram o Rio Nilo, as planícies chinesas, a Mesopotâmia, as planícies indogangética eram: as civilizações de regadio, isto é, tinham a técnica para o controle dos rios por meio de canais construídos através de obras públicas como as encontradas no Rio Nilo no passado; um estado teocrático em que os governantes eram vistos como divinos, representantes dos deuses na vida terrena; as terras eram controladas pelo estado; a existência do trabalho compulsório (obrigatório): os camponeses deviam impostos que eram pagos sob a forma de trabalho.

Dentre as civilizações mesopotâmicas, há um destaque para os amoritas que para Antropologia jurídica tem relevância, pois constituíram o primeiro código de leis conhecido como "Código de Hamurabi", cuja marca principal era a frase "olho por olho, dente por dente" logo demonstra o fim jurídico de estabelecer a ordem. Encontramos os fenícios que realizavam a navegação e praticavam o comércio além de fundar feitorias e entrepostos comerciais, não chegaram a formar um império, mas tinham a organização política baseada em espécies de cidades-estado.

$\mathrm{Na}$ sociedade ocidental, destacam-se a grega e a romana. A primeira foi constituída por cidades-estado devido ao relevo montanhoso que impediu a formação de um império único e as duas cidades-estado que se destacam são Fsparta e Atenas.

Esparta possuía um governo oligárquico cujo poder ficava em mãos da aristocracia participantes dos éforos e do conselho de anciãos chamado gerúsia e já os dois reis, diarquia, tinham apenas o poder religioso.

Atenas teve grande destaque na política que proporcionou estudos aprofundados na atualidade, pois tinha um sistema de governo avançado e diferenciado para a época, a democracia direta em que participavam cidadãos homens, livres, atenienses e maiores de 18 anos. Assim, todo cidadão tinha o direito de votar e participar da eclésia, espécie de assembléia popular que elaborava as leis, realizava julgamentos e a escolha de magistrados.

$\mathrm{Na}$ sociedade romana encontramos basicamente quatro grupos sociais. O topo da pirâmide social era formada pelos patrícios e posteriormente vinham us clientes, os plebeus e os escravos. Dividimos o estudo de Roma em períodos como o da monarquia em que a havia o Rei governando juntamente com o Senado formado por patrícios, a elite pensante e dominante. Depois. a República em que o Senado é a base do poder político governado por dois cônsules. E é nesse período que importantes 
conquistas jurídicas obtidas pelos plebeus ocorreram e dentre elas podemos citar a Lei das Doze Tábuas. A crise da república traz o fortalecimento do exército e o início do periodo imperial governado pelos generais romanos. Roma enfraqueceu com o decorrer dos tempos devido a quida de riquezas, número de escravos e de produção, além do constante avanço do Cristianismo pelo ocidente. Isso permitiu às invasões bárbaras no Impírio romano culminando com o seu fim na sua parte ocidental.

$\mathrm{O}$ início das invasões bárbaras gera uma outra época denominada Idade Medieval em que as sociedades eram estamentais e a nobreza, senhores feudais, detinha o maior poder político em detrimento do poder real. A instabilidade nas cidades gerava o êxodo urbano. fuga dos indivíduos para os feudos fortificados em busca de proteção, e o início da servidão e concretização do vínculo suserania e vassalagem.

A parte oriental do Império romano era a civilização bizantina. A organização social da Roma Oriental era comandada pelo imperador. este que controlava o exército e a Igreja, sendo considerados os representantes de Deus. O mais célebre governante do Império bizantino foi Justiniano que ampliou as fronteiras do Império, empreendendo expedições que chegaram à Península lbérica e ao Norte da África. Uma das maiores relevâncias para a Antropologia Jurídica está na obra realizada por Justiniano fora a compilação do Direito Romano, organizado em partes: Código (conjunto de leis romanas desde o século II), Digesto (comentários dos grandes juristas a essas leis), Institutas (principios fundamentais do Direito Romano) e Novelas (novas leis do período de Justiniano). O conjunto desses trabalhos resultou num dos maiores legados do mundo romano: o Corpus Iuris Civilis, que serviu de base aos códigos civis de diversas nações nos séculos seguintes. Essas leis definiam os poderes quase ilimitados do imperador e protegiam os privilégios da Igreja e dos proprietários, marginalizando a grande massa de colonos e escravos.

Havia nesse período da Idade Média uma civilização formada por meio da religião, a muçulmana. Antes do século VIl, os árabes viviam como tribos nômades, como os beduínos, e sedentários, a exemplo das como as tribos localizadas em oásis, eram politeístas e havia constantes conflitos internos. Até que Maomé perseguido por prugar o monoteísmo. deus único Allah, a poligamia, a doação de esmolas, o jejum, entre outros foge de Meca para latreb (Medina). Essa fuga foi chamada de Hégira e marca o início do calendário árabe. Maomé morre em 632 e deixa a Arábia unificada, sob uma mesma religião e um ideal comum: a djihad ("guerra santa"), que consistia na luta pela conversão do "infiéis" e que, nos séculos seguintes, propiciaria a expansão islâmica.

No final Idade Média. houve o fim das invasões bárbaras e os feudos começaram a sofrer de superpopulação, levando seus habitantes a procurarem atividades 
fora dos domínios senhoriais. Isso gerou uma maior movimentação de pessoas e a intensificação do comércio urbano que estava em estado letárgico, além do desenvolvimento de burgos e surgimento e fortalecimento de uma nova classe social, a burguesia mercantil.

É a partir do desenvolvimento da burguesia mercantil e o intuito do rei em recuperar seu poder, que surgem os primeiros Estados Modernos. Essa convergência de interesses é fator determinante para entendermos certos países como Portugal, Espanha, Inglaterra e França emergiram do feudalismo para a organização estatal na Europa Ocidental. Portanto, o enfoque principal, nesse trabalho, se inicia nesse período em especial.

\section{Teorias para a origem da sociedade}

A grande discussão desse tópico se deve ao fato de existir duas possiveis teorias para justificar a origem da sociedade. Uma delas, seria a sociedade natural e em contraposição o contratualismo. Portanto, as grandes questões em pauta são se o homem é naturalmente um ser sociável ou se ele aceita as limitações impostas pela vida social por vontade própria ou necessidade através de um contrato.

A teoria da sociedade natural, a de maior aceitação, teve início com grandes pensadores filosóficos e políticos como Aristóteles em A Política: ele afirmava "o homem é naturalmente um animal político" E com Cícero no século I a.C. no livro Da República que dizia "a primeira causa da agregação de uns homens a outros é menos a sua debilidade do que um certo instituto de sociedade em todos inato; a espécie humuna não nasceu para o isolamento e para a vida errante, mas com uma disposição que, mesmo na abundância de todos os bens, a lcva procurar o apoio comum". logo uma reafirmação para a frase dita pelo filósofo citado anteriormente. E São Tomás de Aquino, grande seguidor de Aristóteles, afirmou em seu livro Suma Teológica que "o homem é, por natureza, animal social e politico, vivendo em multidão, ainda mais que todos os outros animais, o que se evidencia pela natural necessidade", mas ele também garante que a vida solitária é uma exceção e haveria três hipóteses para justificá-la: excellentia naturae, quando se tratar de um indivíduo virtuoso, que vive com a própria divindade, como os eremitas; corruptio naturue, referente aos casos de anomalia mental; mala fortuna, quando só por acidente o indivíduo passa a viver em isolamento.

Ainda adepto a essa teoria natural Ranelletti afirma que o homem sozinho, isolado dos outros, não se encontra na realidade da vida. Fle demonstra a necessidade do agrupamento e aglutina a teoria com a realidade. F para justificar sua afirmação o autor 
diz que a associação é devida a necessidade de satisfazer suas próprias vontades, para atingir os fins de sua existência.

Sendo assim, essa associação de indivíduos tem o objetivo de atingir os fins de sua existência que não-só é de ordem material como também os de ordem essenciais para permitir-lhes a sua sobrevivência. É importante ressaltar que o ser humano, por ser uma animal racional, escolhe viver em grupo voluntariamente, pois reconhece que necessita dessa convivência em sociedade para o próprio bem. Isso o diferencia dos animais irracionais que se agrupam por instinto.

A teoria em oposição à natural é a contratualista. Ela tem como base a decisão do homem em conviver em sociedade aceitando as limitações impostas pela organização social.

Um dos representantes mais importantes dessa teoria é Thomas Hobbes que, em seu livro Leviatã, descreve o homem como um ser que vive o "estado de natureza", ou seja uma desordem, portanto em seu estado primitivo da História. Assim, percebe-se que suas atitudes são irrefreadas necessitando, pois, de uma presença de uma força maior para trazer a ordem. Esse "estado de natureza" ¿́ uma ameaça a toda sociedade justificado pela expressão do próprio autor "guerra contra todos" e por viver essa instabilidade, celebra-se o contrato social em que o poder ficaria concentrado em mãos de um soberano responsável por todos e este se falhar em seu mandato poderá ser destituído a fim de buscar alguém qualificado a assumir esse posto de comando da sociedade contratual. O poder desse governo não deve sofrer limitações e ele também por pior que seja, seria melhor que o estado de natureza. Sabc-se que Hobbes é um absolutista e seu livro, datado de 1651, confirma essa sua teoria em busca de uma sociedade governada por um soberano e seguida por seus súditos.

Em contraposição a Hobbes e ainda um contratualista está John Locke. Ele, em Segundo Tratado sobre o Governo, concorda a existência de um "estado natural" mas discorda da constância de um caos, "guerra contra todos" e sim uma possibilidade para que ele ocorra. Para que houvesse uma organização, estabeleceria-se um contrato que conseqüentemente geraria uma sociedade política, o Estado, com poderes limitados e obrigada a respeitar os direitos naturais, sendo eles a igualdade, a família e a propriedade privada, além da divisão de poderes em Executivo e Legislativo.

Um terceiro contratualista e de grande importância é Jean Jacques Rousseau. Ele afirma que é a vontade e não a natureza humana o fundamento da sociedade. O pensador percebe como há a necessidade de todos se protegerem e defender suas respectivas propriedades por meio de uma força comum. Assim, surge uma associação de indivíduos entregando a uma soberania o poder de decisão e um 
Estado como mero executor de decisões. É importante ressaltar que essa soberania atuante seria responsável pelo interesse de um todo e cada componente do grupo detentor do poder teria uma vontade própria que seria indiretamente a "vontade geral"

Há a entrega, pois, do poder a um determinado grupo soberano responsável da governabilidade, a fim de evitar a desordem. Esse "contrato social" feito demonstra uma certa igualdade jurídica e a definição do pacto social fica muito bem expressa na frase: "Cada um de nós põe em comum sua pessoa e todo seu poder sob a direção suprema da vontade geral, e recebemos, enquanto corpo, cada membro como parte indivisível do todo"

A predominância da primeira teoria demonstra que o homem é um ser naturalmente social, a fim de satisfazer suas próprias necessidades e com a participação da razão. Embora a natureza em grupo seja mais aceitável teoricamente, é o contratualismo que explica, na prática, uma organização social baseada na democracia. Portanto, podemos mesclar essas duas teorias divergentes para compreender que o homem é um animal social que através do contrato se relaciona e dificilmente viveria isolado.

\section{Sociedades eficientes sem Estado}

Quando se estuda um agrupamento social, não há como não se pensar em uma nação. Embora a grande maioria das diferentes sociedades do planeta esteja organizada, sob domínio de uma forma de governo comandada pelo Estado, ainda é possivel encontrar, nos dias de hoje, povos sem moradia fixa vivendo à base de caça e troca de produtos.

No livro Antropologia Juridica, Robert Weaver Shirley cita dois elementos essenciais atuantes em um grupo anárquico politicamente: o primeiro seria a família, pois esta é responsável, antes de tudo, pela incorporação de valores e da cultura legal de uma sociedade aos seus membros mais jovens e depois, porque ela é a primeira frente de punição a uma conduta incorreta cometida por um membro familiar e isso ainda é aplicado em sociedades orientais como o Japão. China e Coréia. E o segundo elemento crucial em uma sociedade simples é a comunidade. A definição para a comunidade segundo Shirley é "um grupo co-residencial que vive todos os dias frente a frente." O autor exemplifica ao citar sociedades caçadoras em que dentro deste grupo os melhores sucedidos na caça repartem com os indivíduos menos favorecidos na comunidade trazendo, pois, uma igualdade e proporcionando um equilíbrio nesse meio social. 
Em vista disso, a maioria das sociedades sem Estado desenvolveu elaboradas maneiras de sanções sociais e psicológicas, a fím de dar uma advertência adequada ao infrator, e também receber o apoio da comunidade antes de qualquer decisão séria.

Um grupo social desprovido de Fstado e ainda presente nos dias de hoje com estabilidade é o dos esquimós. Seu êxito esta nas suas leis muito bem elaboradas com uma série de progressivas sanções o que traz uma certa eqüidade e organização.

Robert Weaver Shirley mostra exemplos em seu livro dessa ordem estabelecida pelos esquimós por meio de leis sancionais. Uma delas é o escárnio em que há a diversão com os defeitos dos outros entendidos como egoísmo, cobiça, ou orgulho excessivo. O objetivo é ridicularizar uma determinada pessoa que traz desgosto a outra em público, com a finalidade de ganhar apoio da comunidade. Outro exemplo são as disputas constantes em yue o ofendido pelo escárnio tem o direito de desafiar o ofensor para uma competição feila por meio do canto e da música. Essa é uma maneira de expressar hostilidade em público evitando um confronto violento. Um terceiro exemplo seria recorrendo à influência de um ancião respeitado em que o indivíduo deve ser parente do acusado e o ofendido precisa ser capaz de persuadi-lo da seriedade do problema e de que este é do interesse da comunidade. Um exemplo mais violento seria o homicídio em que o ofendido tem a faculdade de tentar matar seu inimigo. $\mathrm{E}$ os resultados podem correr de duas maneiras diferentes: a primeira. se o ofendido conseguir apoio da comunidade, poderá recrutar indivíduos inclusive parentes do próprio inimigo para ajudá-lo, já na segunda maneira. se o acusador não tiver apoio da comunidade. poderá agir sozinho com a possibilidade de represália por parte de parentes da vítima.

Diante dessa organização, percebe-se que o apoio da comunidade para agir de uma maneira única serve como uma unidade de poder com o objetivo de sancionar o infrator e gerar justiça. Além disso, não há delitos conta a comunidade somente contra um indivíduo embora possa haver pessoas condenadas pelo grupo social por uma série de delitos individuais.

Conclui-se que a necessidade de um Estado pode ser questionada quando se observa um grupo social tão bem organizado como os esquimós. Atualmente, eles possuem um território na região do Canadá, o Território Nunavut, e são chamados ynuits. A grande dificuldade é conter a expansão do "homem branco" para terras no norte do Canadá, em busca de recursos minerais. Isso traz uma instabilidade aos ynuits que vivem da caça e da pesca e uma simples mudança do ecossistema local geraria um desequilibrio, logo uma possivel extinção de um povo tão incomum nos tempos modernos. 
Uma Nação politicamente organizada

5. A origem e formação do Estado

Existem muitas teorias sobre a época e surgimento do Estado e as mais proeminentes são: a que o Estado assim como a própria sociedade sempre existiu, pois uma vez que o homem vive sobre a Terra, é integrado em uma organização social competente e capaz de direcionar todo um grupo quanto a comportamentos e condutas. Uma outra teoria induz a formação de um Estado para atender às necessidades ou às conveniências dos grupos sociais. Portanto, essa organização política foi surgindo em cada lugar em tempos diferentes a partir de determinadas condições propicias a seu nascimento. E uma terceira teoria defende que o Estado possui uma sociedade dotada de certas características muito bem definidas. Karl Schmidt diz que o conceito de Estado não é um conceito geral válido para todos os tempos, mas é um conceito histórico concreto, que surgem quando nascem a idéia e a prática da soberania. logo somente no século XVII. Outro defensor desse mesmo ponto de vista é Balladore Pallieri em que diz "a data oficial em que o mundo ocidental se apresenta organizado em Estados é a de 1648, ano em que foi assinada a pa $\angle$ de Westfália"

Quanto às causas do aparecimento dos Estados, há duas questões divergentes: a formação originária dos Estados, partindo de agrupamentos ainda nãointegrados em qualquer Estado; e a formação derivada defendendo o surgimento dos Estados a partir de outros já preexistentes.

As principais teorias da formação originária são classificadas em dois grupos: teorias que defendem a formação natural do Estado não havendo entre elas uma coincidência quanto à causa, mas tendo todas em comum a afirmação de que o Estado se formou naturalmente, não por um ato voluntário: e as teorias que defendem a formação contratual dos Estados, apresentando em comum, apesar da divergência entre si quanto às causas, a crença em que foi a vontade de alguns homens. ou então de todos os homens resultando na criação do Estado.

Em relação às causas naturalistas de aparecimento do Estado podem ser agrupadas da seguinte maneira: origem patriarcal ou familiar tem como núcleo fundamental a família para a origem do Estado; origem em atos de força, de violência ou de conquista demonstra que o Estado nasce por meio da submissão de grupos dominados a grupos dominadores estes devido a superioridade de poder; origern em causas econômicas ou patrimoniais definida por Heller dizendo que a posse da terra gerou o poder e a propriedade gerou o Estado; origem no desenvolvimento interno da sociedade 
em que segundo Robert Lowie, o Estado é um germe, uma potencialidade, em todas as sociedades humanas, as quais, todavia, prescindem dele enquanto se mantêm simples e pouco desenvolvidas.

A criação do Estado por formação derivada é o processo mais comum atualmente. Dentro dessa teoria há processos típicos e opostos que dão origem a novos Estados: o fracionamento e a união de Estados. O primeiro foi comum em tempos de fim da Guerra Fria em que muitos países surgiram por terem se desmenbrados da URSS e esse ainda é um grande motivo de guerras internas na Rússia que evita que muitas repúblicas se tornem independentes como países do Leste europeu que antes pertenciam à URSS; e o segundo processo foi presenciado na formação dos Estados Unidos da América em que a Guerra de Independência das 13 colônias deu origem a esse país da América do Norte, e ainda atualmente vive-se uma tentativa de união para se constituir um único Estado europeu que hoje é formado por países da União Européia.

6. As teorias triádicas do Estado

As teorias triádicas do Estado o definem como a união de elementos soberania, povo e território.

Para um maior entendimento dessa tríade muito estudada e difundida no mundo todo, a formação do primeiro Estado Moderno, Portugal, pode servir como um exemplo prático da teoria.

Antes de explicitar a situação de Portugal e a maneira que foi possível a formação do primeiro Estado Moderno, o contexto histórico será descrito a fim de fundamentar essa ocorrência.

No princípio do século XV. a Europa atravessava uma fase de profundas modificações econômicas, sociais e políticas. Embora algumas delas tenham ocorrido bem antes, século XII, foi no decorrer do século XV que atingiram seu ponto máximo, ocasionando a desagregação das velhas instituições da Idade Média e dando início à Idade Moderna, séculos XV a XVIII.

$O$ processo de alterações principiou no final do século XI. quando o império árabe, o Califado de Bagdá, entrou em decadência e fragmentou-se numa multidão de pequenos reinos.

Conseqüentemente, terminou o domínio árabe sobre o Mar Mediterrâneo. o que permitiu o início da navegação européia, interrompida em virtude do monopólio marítimo exercido pelos árabes desde o século VII. Com a reabertura do Mediterrâneo à 
navegação européia, houve um renascimento comercial tão intenso que já no século XV o comércio era a mais importante e lucrativa atividade econômica da Europa.

Esta alteração na economia ocasionou importantes modificações na estrutura social européia. Desta forma, a burguesia comercial transformou-se na classe detentora do poder econômico. Assim, a nobreza feudal, que durante tantos séculos dominara a sociedade européia, perdeu parte significativa de sua força econômica, embora mantivesse sua influência política. Outra conseqüência para o desenvolvimento comercial foi a expansão das áreas urbanas em detrimento das rurais.

Estas transformações econômicas e sociais geraram alterações também no campo político controlado pela nobreza. A partir do século XIV, os reis se aliaram à burguesia no combate à nobreza: o poder dos nobres diminuiu e o dos reis aumentou. Este processo de fortalecimento político da realeza foi a centralização monárquica e levou em diversos países europeus à formação do Estado Nacional Moderno.

Portanto, no século XV, a civilização da Europa Ocidental assentava-se em três pontos básicos: comércio, burguesia e monarquias fortes.

Neste mesmo século, o comércio europeu sempre em busca de novos produtos e mercados sentiu necessidade de se estender além das fronteiras européias, em direção à África e ao Oriente. A burguesia e os governos europeus iniciaram, então, o movimento caracterizado de Expansão Ultramarina Européia, iniciada por Portugal e continuada, posteriormente, pela Espanha, Holanda, França e Inglaterra.

No século V, a Península Ibérica fazia parte do Império Romano do Ocidente. Após a Grande Invasão dos bárbaros sobre as terras do Império, a península foi dominada pelos visigodos, que nela instalam o Reino Visigótico, mais tarde aderindo ao Cristianismo.

Quando no século VIII os muçulmanos em expansão invadem a península, desintegrando o Reino Visigótico, os cristãos fugiram para o Norte, onde se formaram os pequenos reinos de Leão, Navarra, Aragão, Castela e Galiza.

No século XI, os reinos uniram-se, sob a liderança de Afonso VI, para expulsar os muçulmanos. Henrique de Borgonha, um dos nobres europeus que auxiliou na Reconquista, recebe a recompensa de Afonso VI, rei de Leão, o Condado de Portucalense e a mão de Da. Teresa, filha bastarda do Rei.

Após a morte de Henrique de Borgonha, seu filho Afonso Henriques, vencendo os castelhanos e reconquistando terras em mãos dos "infiéis", proclamou a independência do Condado de Portucalense, em 1140. Foi, portanto, com Afonso Henriques que se originou o reino de Portugal. iniciando-se também a dinastia Borgonha. 
Os Reis desta dinastia dedicaram-se à expansão territorial, lutando contra os muçulmanos, o que estimulou o povoamento e agricultura das áreas conquistadas. A longa fase de lutas fortaleceu o poder real, contribuindo assim para uma precoce centralização monárquica em Portugal. Enquanto no interior se desenvolveu a agricultura, no litoral desenvolveu-se o comércio, favorecido pelas facilidades comerciais decorrentes da centralização monárquica e pela posição geográfica do Reino, por onde passavam importantes rotas comerciais. Com isso enriqueceu-se o grupo mercantil luso. Foi na Revolução de Avis que houve a mais profunda e permanente das revoluções portuguesas.

Com a morte de D. Fernando, último Rei da dinastia de Borgonha, o problema da sucessão colocou em choque a nobreza e o grupo mercantil: a viúva $\mathrm{Da}$. Leonor e a nobreza queriam anexar Portugal a Castela. sob o pretexto de que a filha do Rei falecido era casada com o Rei de Castela. O grupo mercantil e o povo queriam Portugal independente. Após várias batalhas entre portugueses e castelhanos, estes foram vencidos pelas forças comandadas por Nuno Álvares Pereira, na Batalha de Aljubarrota, em 1385, D. João foi então proclamado Rei de Portugal fundador da dinastia de Avis.

O feudalismo português desmoronou com a Revolução de Avis e se comparado com o inglês e francês, apresentava um modelo próprio em que o Rei e os súditos não havia intermediários, onde o poder político era centralizado.

Analisando esses fatos históricos, identificaremos os três elementos essenciais para a formação do Estado Moderno. O primeiro elemento, a soberania. que é o poder de uma Nação de organizar-se juridicamente e de fazer valer dentro de seu território a universalidade de suas decisões nos limites dos fins éticos de convivência segundo Miguel Reale em Teoria do Direito e do Estado, é verificada após D. João, para evitar uma possivel submissão do Condado de Portucalense à Espanha, coordena uma série de batalhas junto ao povo português contra os espanhóis e tem por fim a vitória e independência do Condado Portucalense que inicia o reino de Portugal, sendo este uma soberania uma vez que proporcionou um bem comum ao povo luso e constitui-se como Estado independente.

Na definição de soberania, Miguel Reale em seu livro desdobra em três sentidos: soberania seria o poder que possui uma sociedade historicamente organizada integralizada como Nação, o grau mais alto de integração social até hoje alcançado pela convivência humana, de se constituir em Estado independente, pondo-se como pessoa jurídica (esse conceito é a apreciação histórico-social da soberania); soberania é o poder de uma Nação juridicamente constituída, é o poder da pessoa jurídica estatal na forma do ordenamento jurídico objetivo que se concretiza com expressão do máximo grau de 
positividade (é a apreciação técnico-jurídica); e soberania é o meio indispensável à realização do bem comum em toda convivência nacional (é a expressão ético-política).

Já no conceito de povo, podemos perceber como o grupo social que progredia, comercializava na região do Condado Portucalense se via como uma única Nação e isso foi crucial na busca dos próprios interesses principalmente na união contra o inimigo comum, a Espanha. Há autores que conceituam o povo como o conjunto de cidadãos do Estado, no fato citado seria o Estado em potencial.

Jellinek citado por Dalmo de Abreu Dallari observa o povo como dois possiveis sentidos: os indivíduos, enquanto objetos de poder do Estado, estão numa relação de subordinação e são, portanto, sujeito de deveres; enquanto membros do Estado, os indivíduos se acham, quanto a ele e aos demais indivíduos, numa relação de coordenação, sendo neste caso, sujeitos de direitos. Essas duas possíveis definições se aplicam a Portugal, pois foi um Estado em potencial antes de receber o título de Estado Moderno, Reino de Portugal. O povo tinha uma relação de subordinação para com o seu soberano, o líder D. João. portanto sujeito de deveres ou em uma outra visão eram membros do Estado em formação e esses indivíduos se encontravam em coordenação sujeitos de direitos em busca de um objetivo comum, a independência do Condado.

O terceiro e último elemento da triade do Estado é o território. Ele pode ser notado quando um simples povo mercante passou a dominar regiões da Península Ibérica e expulsar os mouros que ali ocupavam. A estimulação do povoamento e da agricultura proporcionou uma estabilização do grupo social e um crescimento populacional. A fixação definitiva na Península Ibérica ocorreu após a vitória dos portugueses contra a Espanha e a denominação Reino de Portugal delimitou a extensão do reinado sendo este conhecido como seu território.

\section{A finalidade do Estado}

O objetivo desse tópico é explicitar o conceito para que se possa compreender a situação atual de diversas Nações. Demonstrar falhas a fim de comprovar como não há realmente uma finalidade absoluta e justa para as atitudes dos Estados para com outros Estados e seus cidadãos é também motivo desse esclarecimento.

Uma teoria muito difundida nos Tempos Modernos é de que o Estado tem como finalidade de realizar o bem comum, isto é, o conjunto de todas as condições de vida social que consintam e favoreçam o desenvolvimento integral da personalidade humana. 
É trazer o bem comum a um certo povo de um determinado território, logo este bem comum é peculiar de cada povo.

Os contratualistas diziam em suas teorias que os homens se alienam a uma figura maior porque a finalidade é a superação do "estado de natureza" e a formação de uma sociedade civil. Esse "estado natural" seria prejudicial à sociedade, pois haveria um estado de guerra constante, "guerra contra todos" como dizia Hobbes ou então a possibilidade do caos entre os homens por parte de Locke e Rousseau afirmava que para evitar isso, deveria existir a "soberania do povo" O primeiro usa o Direito com a vontade do soberano para garantir o contrato de submissão entre o detentor do poder e os súditos e Rousseau só considera a lei a expressão da vontade geral que por sua vez é a expressão do "eu comum", o verdadeiro soberano. E também afirmava que o Estado era uma pessoa, um corpo social em que se concretiza a vontade comum. Locke demonstra em sua teoria como o principal objetivo de uma sociedade política seria a preservação da propriedade.

E na atualidade, podemos citar o exemplo do Estado de Bem-Estar (Welfare State) ocorrido na "era de ouro" entre os últimos anos da década de 1940 e os primeiros da década de 1970.

As conseqüências da crise de 1929, que resultaram na Grande Depressão, simbolizam um importante ponto de ruptura na história do sistema capitalista. A partir desses episódios, tornava-se claro que não era possível a continuidade do sistema sem crises se não existissern mecanismos que de alguma forma disciplinassem a economia de mercado.

Restava definir quem ou qual instituição caberia a responsabilidade de propor as medidas saneadoras. Ocorria, então, uma conjuntura política que colocava em relevo os Estados Nacionais nesse papel. Segundo essa visão, a União Soviética fora imune à Grande Depressão e os regimes nazifascistas também teriam tido condições de promover a recuperação econômica. No ano de 1936, é publicada a obra de John Maynard Keynes A Teoria Gerul do Emprego, do Juro e da Moeda que viria formalizar o conjunto de medidas necessárias para que não ocorressem mais crises como a de 1929 no sistema capitalista. As formalizações e as aplicações das políticas propostas por Keynes. de alguma forma, viriam a dar origem ao chamado Estado de Bem-Estar.

Tratava-se, em última instância, de conferir poderes au Estado para interferir na economia, no sentido de preservar a economia de mercado. Criar mecanismos que gerassem emprego e, por sua vez, estimularia a produção, revertendo dessa forma o "círculo vicioso da pobreza" no sentido de um "círculo vicioso da riqueza" 
Portanto, caracterizou o chamado Estado de Bem-Estar, entre outros aspectos, um papel de disciplinador de atividades econômicas no sentido de produzir um equilíbrio entre a oferta e procura, entre os interesses do capital e os do trabalho. Além disso, a economia reguladora visava o investimento maciço em educação, habitação e saúde tendo muitos adeptos a esse modelo econômico como Estados Unidos, Europa Ocidental e Japão.

Essa finalidade de garantir o bem-estar social, infelizmente, apresentou falhas ao ser aplicada na prática. Entre elas está a dificuldade de criar empregos suficientes para suprir a demanda o que gera um aglomerado de pobres e realça a desigualdade. E o agravante está na defesa do "Estado Mínimo" nos tempo atuais em que os neoliberais menosprezam o papel do Estado na indução ao desenvolvimento e na prática de políticas sociais que asseguram aos mais pobres a esperança de um dia serem cidadãos. Afinal, não é o mercado quem há de oferecer educação e saúde públicas gratuitas e de boa qualidade. E onde não houver Estado. estados paralelos surgirão, seja o dos oligopólios multinacionais, seja o do crime organizado, seja o dos meios de comunicação, seja ainda uma combinação dos três. É essa ausência estatal que será discutida no próximo tópico.

\section{O Estado Paralelo como resultado de ineficácia}

Para a definição do surgimento de um Estado Paralelo, podemos explicar o conceito através da situação atual vivida. Dois exemplos servirão como embasamento desse conceito: o Hamas e $o$ PCC.

\subsection{Hamas}

O Hamas que é um movimento político palestino, cuja sigla designa o Movimento de Resistência Islâmica. O grupo. criado em 1987 no início da primeira Intifada (revolta palestina), tem como objetivo, a curto prazo, expulsar as forças israelenses dos territórios ocupados, através de ataques contra os soldados e os colonos judeus e. de maneira mais polêmica, contra civis israelenses. Preconiza, portanto, a luta contra Israel por todos os meios em nome dos princípios do Islã. Visando à "libertação do país desde o Rio Jordão até o mar" o Hamas é responsável por várias ações armadas. Muito popular nos territórios ocupados, onde seu radicalismo torna-o um concorrente sério da Organização para a Libertação da Palestina (OLP). Violentamente hostil às negociações de paz entre Israel e a OLP. respondeu com atos terroristas à instalação, em 
1994, na Faixa de Gaza e em Jericó, do regime autônomo previsto pelo acordo de Washington, de 1993.

O grupo militante Hamas, a principal organização islâmica militante palestina, parece ter traduzido a popularidade de sua luta em votos, vencendo as primeiras eleições parlamentares palestinas desde 1996, realizadas em janeiro de 2006.

Considerada uma organização terrorista por Israel, Estados Unidos e União Européia. o grupo é visto por seus correligionários como uma força legitima de luta defendendo os palestinos da brutal ocupação militar israelense.

O Hamas insiste que a retirada israelense da Faixa de Gaza em 2005 foi uma vitória de sua política e também tem o objetivo de, a longo prazo, estabelecer um Estado islâmico em toda a Palestina histórica, cuja maior parte permanece dentro das fronteiras de Israel desde sua criação, em 1948.

Desde a morte do líder palestino Yasser Arafat, o Movimento de Resistência Islâmica vem participando de eleições locais e conquistou várias cadeiras em áreas como Gaza. Qalqilya e Nablus.

A organização, formada por um braço político e outro militar, tem um número desconhecido de integrantes, mas conta com dezenas de milhares de correligionários e simpatizantes. E ela se divide em duas principais esferas de operação: programas sociais, que incluem a construção de escolas, hospitais e instituições religiosas; e operações militantes lideradas pelas Brigadas Izzedine al-Qassam, um grupo clandestino. O Hamas age, pois como um verdadeiro Estado Paralelo garantindo o bem estar de um grupo social em prol de ganho de popularidade e credibilidade de suas ações.

O grupo ganhou fama depois da primeira Intifada como o principal opositor palestino aos Acordos de Oslo - o processo de paz liderado pelo governo americano que previa a remução gradual e parcial das tropas israelenses nos territórios ocupados, em troca de compromissos das autoridades palestinas de proteger a segurança de Israel.

Em fevereiro e março de 1996, organização islâmica militante palestina cometeu uma série de atentados suicidas, causando a morte de quase 60 israelenses, $\mathrm{cm}$ retaliação contra o assassinato um de seus membros em dezembro de 1995.

Atribui-se a esses atentados a decisão de Israel de se retirar do processo de paz e a eleição do linha-dura Binyamin Netanyahu, um claro oponente dos acordos de Oslo.

Com o fim dos acordos de Oslo. e principalmente depois da fracassada tentativa de retomada do processo de paz no encontro de Camp David, em meados do ano 2000 , e a segunda Intifada, iniciada meses depois. o Hamas ganhou força e 
influência enquanto Israel destruia sistematicamente a infra-estrutura da secular Autoridade Palestina.

Nas cidades e campos de refugiados sitiados pelas tropas israelenses, o Movimento de Resistência Islâmica organizou clínicas e escolas para os palestinos, que se sentem totalmente decepcionados com a corrupta e ineficiente Autoridade Nacional Palestina. O grupo também executou sumariamente colaboradores palestinos e adotou punições para "comportamento imoral"

Muitos palestinos concordam que as operações suicidas são a melhor maneira de se vingar de Israel e, apesar das inúmeras tentativas de unir as várias facções palestinas, a organização islâmica militante palestina sempre se esquivou de assinar um cessar-fogo permanente enquanto Israel ocupar os territórios palestinos.

Nesse cenário, percebe-se a clara existência do Estado Paralelo uma vez que o Fstado de lsrael, criado pela ONU em 1948, não foi capaz de conter as instabilidades políticas na discussão histórica ligada à posse real do território da Palestina, no Oriente Médio. A população árabe se sente isolada visto que os israelenses recebem ajuda direta de países ocidentais como os Estados Unidos da América e possuem tecnologia de ponta no cultivo de alimentos em pleno deserto. A desigualdade entre as regiões é evidente o que fortalece na ação e credibilidade do Estado Paralelo Hamas.

A organização islâmica militante palestina recebe apoio da população não só porque ela oferece ajuda econômico-social na região desenvolvendo a infra-estrutura como também por causa do motivo maior religioso, a criação de um Estado palestino islâmico. Aqui percebe-se uma forte influência religiosa baseada no fundamentalismo islâmico para legalizar atos terroristas e obter concessões políticas. Esse Estado Paralelo é, pois. uma organização política que cresceu à custa desse fanatismo religioso juntamente da ausência de um Estado capaz de garantir o bem-estar de seu povo.

\subsection{PCC (Primeiro Comando da Capital)}

Essa é uma organização criminosa que teve como início no Brasil, em 1993. em um anexo da Casa de Detenção em Taubaté, São Paulo, a partir de um time de futebol. Primeiro Comando da Capital foi o nome escolhido por José Márcio Felício, o "Geleião", que hoje está jurado de morte por ter entregado os companheiros. Lm 2001, o PCC organiza uma megarrebelião em 24 presídios e cinco carceragens de delegacias do Estado de São Paulo, o cue se tornaria até então o maior motim da história deixando 8 mortos e 22 feridos. Em 2002, o Governo de São Paulo monta um organograma da 
estrutura do PCC. No mesmo ano, o diretor do DEIC, Godofredo Bittencourt, diz que a faç̧ão criminosa é uma instituição falida, sem mais força no Estado. Em 2006, a organização comanda uma série de mais de 300 atentados, que inclui ataques a ônibus, a instituições bancárias e a escolas e resultou em mais de 170 mortos e em 82 rebeliões, causando uma das maiores crises da segurança em São Paulo.

A aparição dessa faç̧ão criminosa, e sua permanência até os dias de hoje, demonstra a ineficácia do Governo brasileiro em garantir a segurança pública assim como oferecer a infra-estrutura social necessária para que não houvesse essa propagação tão alarmante de adeptos do crime no território paulista.

A falha do Estado para conter essa expansão criminosa é evidente e especialistas apontam quais os erros mais claros nessa falta de preocupação Estatal. A advogada Karyna Sposato, diretora executiva do Ilanud (Instituto Latino-Americano das Nações Unidas para a Prevenção do Delito e Tratamento do Delinqüente), diz que o crime organizado está "reagindo frontalmente contra o Estado democrático" Ela acredita que, além do Executivo, outros atores envolvidos na segurança pública, como o Ministério Público c a Justiça, também têm responsabilidade sobre a situação "caótica" do sistema prisional paulista. Segundo ela, é preciso que o Estado crie presídios específicos para cada tipo de delito e desenvolva mecanismos para evitar que seus policiais colaborem com os criminosos: "Não existe crime organizado sem a conivência de agentes policiais"

$\mathrm{Na}$ avaliação do consultor em segurança pública José Vicente da Silva, exsecretário nacional de Segurança, a falta de sintonia entre as secretarias paulistas de Segurança e da Administração Penitenciária é uma das razões da vulnerabilidade do sistema prisional. Seria preciso implantar um sistema de inteligência prisional que investigue as ações das facções criminosas dentro das penitenciárias. Silva afirma que todas as instâncias do governo, juntamente com o Ministério Público e a Justiça, deveriam examinar os fatos e avaliar as falhas. Diz "É preciso fazer ajustes na legislação penal, ver até que ponto houve liberdade demais em visitas intimas e de advogados que, às vezes, atuam como "pombos-correios dos criminosos"

E Ariel de Castro Alves, coordenador do Movimento Nacional de Direitos Humanos, diz que os atos criminosos são reflexos do descaso na área social, de segurança pública e Justiça, da falta de cumprimento da Constituição Federal e da legislação penal.

Nessa ausência Estatal, o Estado Paralelo, PCC, pôde emergir e se fortalecer de uma maneira organizada a fim de receber com um sindicato. A facção atua como uma associação de criminosos, que articula assaltos, resgates de presos, organiza o 
tráfico de drogas e arrecada dinheiro com a mensalidade de criminosos e oferece proteção aos integrantes.

O funcionamento desse grupo organizado é definido da seguinte maneira: os criminosos são coagidos a darem contribuições de cerca de $\mathrm{R} \$ 500$ mensais ao PCC ou uma parcela dos crimes realizados; as "lotações" os donos de vans são obrigados a darem uma porcentagem de seus rendimentos de suas linhas: os "bin ladens" são criminosos em dívida com o PCC que recebem a opção de executar ações para a faç̧ão. O não-cumprimento dessas ordens deixa o devedor e sua família sob ameaça; os simpatizantes como cantores de "funk" da Baixada Santista usam homenagens como moeda de troca. Não recebem ajuda financeira, mas ganham proteção e respeito associando seu nome ao PCC. Dentro da facção, existem cerca de seis tesoureiros do PCC em São Paulo. Eles são encarregados de receber contribuições, que variam de R\$ 50 (vindos de detentos) a R 500 (vindos de criminosos soltos), ou checar o depósito dessas quantias, normalmente feito por contas "laranjas" Porcentagens de roubos ou furtos são também direcionados ao PCC; quanto aos advogados, são responsáveis por receber ordens diretas do líder da facção, Marcola, para serem transmitidas fora do presídio; há os "pilotos" que se dividem em "pilotos-detentos" responsáveis por comandar as "faculdades" (presídios), organizando rebeliões e o contato com outros internos em assuntos como contribuição mensal e os "pilotos-gerentes" que ficam fora dos presídios. Cuidam de cada região da cidade de São Paulo, retransmitindo ordens e fazendo articulações com criminosos. O grupo funciona como uma "financiadora" isto é, "empresta" quantias para ações de terceiros e "aluga" o armamento utilizado nos crimes. O pagamento desse "aluguel" é acrescido de parte das quantias obtidas nos crimes. Portanto, ocorre o seguinte: os crimes são financiados pelo grupo; as armas são "alugadas" para a execução dos crimes; os resgates também são financiados; há o pagamento de mensalidades de alunos de faculdade de direito que poderão futuramente trabalhar para a facção; o transporte é viabilizado para as famílias com presos nos "Texas" as penitenciárias do oeste paulista; e o grupo é responsável por ação social na manutenção de creches e ações sociais em favelas. Um último item muito intrigante é relacionado às ramificações políticas em que o PCC já traçou um plano de ter candidatos para os parlamentos brasileiros. O raciocínio era que, considerando 140 mil detentos no Estado de São Paulo, cada um poderia angariar dez votos, e a organização obteria mais de Imilhão de votos.

Em "tendências/debates" do Jornal Folha de S.Paulo do dia. 18 de maio de 2006, quinta-feira, houve uma ressalva do artigo "Civilização, sim; barbárie. não" para a situação de fragilidade ocorrida na cidade de São Paulo no fim de scmana do dia 
13 a 15 de maio de 2006. Muitos autores entre eles Antonio Visconti, Celso Antônio Bandeira de Mello, Fábio Konder Comparato, Goffredo Telles Júnior, Hermann Assis Baeta, João Luiz Duboc Pinaud, José Osório de Azevedo Júnior, Maria Eugênia R. da Silva Telles, Plínio Arruda Sampaio e Weida Zancaner descreveram que apesar do sentimento de medo ter dominado a população paulistana, não seria em curto tempo o problema resolvido. Senadores da República procuraram associar o episódio com terrorismo e prometeram votar uma legislação penal em 15 dias, o que demonstra a probabilidade de ineficácia afinal não se pode tocar em um assunto tão delicado que é o sistema prisional de maneira descomedida. O artigo demonstra com clareza que os atentados ocorridos naquele periodo seriam a explosão de um processo cumulativo, cujo combustivel seria a extrema desigualdade social do país. E que enquanto esse problema não for atacado seriamente pela sociedade brasileira, será impossivel livrar o cotidiano da violência.

Sendo assim, é evidente a ausência do Estado em garantir o bem-estar social aos seus cidadãos e o resultado dessa indiferença é o surgimento de um Estado Paralelo que, em busca de interesses próprios como, por exemplo, expansão do narcotráfico, da ampliação das zonas de influência, acaba oferecendo ajuda social e proteção aos integrantes dessa força paralela por meio da força coativa das armas contra o Estado "real"

O País não pode aceitar esse tipo de atuação criminosa, pois fere com conceito de Estado soberano, por exemplo. em uma das definições dadas por Miguel Reale citadas anteriormente: "soberania é o meio indispensável à realização do bem comum em toda convivência nacional" Se esse bem comum está sendo reprimido por uma força menor que é o Estado Paralelo, é questionável a eficácia de nosso "status quo" Além disso, podemos concluir que se há o crescimento e o fortalecimento dessas facções criminosas, pode-se ter a certeza de que há conivência de setores da sociedade descontentes com a atuação da Federação.

Segundo Eduardo Carlos Bianca Bittar, livre-docente e doutor, professor associado do Departamento de Filosofia e Teoria Geral do Direito da Faculdade de Direito da USP, em seu artigo publicado no Jornal Folha de S.Paulo, ed. n. 28.17I, ano 86, São Paulo. Sábado, 20 de maio de 2006 / Cotidiano, ele afirma que o nosso caso brasileiro, nossa guerra não é de natureza étnica, de natureza política ou de religiosa. A nossa guerra seria de natureza econômica. A justiça e a desigualdade se encontram em uma tamanha proporção que cultivamos em nossos celeiros, dia-a-dia a criminalidade que hoje nos atordoa. 
Ele também afirma que nas sociedades contemporâneas, a associação entre violência e tecnologia facilita a cunhagem de um homem-objeto, de acordo com o protótipo moderno do homem controlado-ordenado, ou seja, de um homem que se torna objeto de consumo em face de uma potencialização cada vez maior de transformação da condição humana em condição inumana. Nesta ocasião, produzimos homens-objeto toda vez que um idoso deixa de ser atendido em um plantão da Previdência Social, a cada vez que uma criança morre por desnutrição, a cada vez que um cidadão tem a justiça denegada, a cada vez que se recorre à corrupção do Estado como única forma de "azeitar" o funcionamento da Justiça.

Desse artigo, podemos inferir que Bittar pretende mostrar a situação social atual do País. A desigualdade domina o território brasileiro, o cidadão "tupiniquim" não é tratado com dignidade e isso é uma forma de violência que a cada dia é alimentada pela ausência do Estado.

Portanto, não se é de duvidar que Estados Paralelos, como o PCC, que têm se demonstrado forte e atuante passem a surgir enquanto o País não der importância a um tópico muito essencial a um Estado sólido, o seu povo, logo o seu bem-estar.

\section{Conclusão}

O homem pelo visto desde muito tempo tem se mostrado um animal que vive em grupo. Vestígios da vida social remontam a um passado longínqüo. Portanto, independente das teorias da origem da sociedade, é inerente se pensar que o ser humano é um ser obrigatoriamente social. Graças a esse tipo de convivência, foi possivel a evolução da complexidade das relações humanas, a ponto de se alcançar o nível máximo de organização social, o Estado.

Embora esse tipo de organização seja considerada a ideal para o estabelecimento da ordem entre as diferentes culturas e civilizações, a existência de um Estado não significa eficiência por completo. Exemplo disso seriam os esquimós, habitantes do Território de Nunavut, no Canadá. Eles continuam sendo sociedade primitiva e vivem à base de caça e pesca no Mundo Contemporâneo. A complexidade de suas leis e normas baseadas em costumes e a manutenção de uma unidade para tomar decisões políticas fortalecem a comunidade ynuit permitindo a sua sobrevivência diante das constantes mudanças sociais e políticas da modernidade.

Sendo assim, não se pode afirmar que uma organização Estatal esteja próxima do ideal para garantir o bem-estar de seus cidadãos, pois pelos exemplos citados de Estados Paralelos, é justo se pensar que independente da organização política de um 
território, a preocupação com a igualdade social é a prioridade. Esses Estados Paralelos são a explicitação da indiferença e de falhas do programa politico-social do Estado para com seu povo. A luta contra a desigualdade social é uma solução esperada, a fim de se restabelecer a força única de um Estado concreto e dar a dignidade que os cidadãos merecem.

A soberania de um Estado depende da ação conjunta entre uma Nação confiante do seu governo e uma organização política em prol do bem de sua população.

São Paulo, dezembro de 2006.

\section{Referências}

SHIRLFY, Robert Weaver. Antropologia Juridica. São Paulo: Saraiva, 1987.

REALE, Miguel. Teoria do Direito e do Estado. 2. ed. São Paulo: Editora Livraria Martins. 1960.

DALLARI, Dalmo de Abreu. Elementos da Teoria Geral do Estado. 25. ed. São Paulo: Saraiva, 2006.

BOBBIO, Norberto. Sociedade e Estado na Filosofia Política Moderna. 3. ed. São Paulo: Editora Brasiliense, 1991.

PARKER, Geoffrey. The Times Allas of World History. 1. ed. Londres: Editora Times Books Ltd., 1993.

SEYMOUR-SMITH, Martin. Os 100 livros que mais influenciaram a humanidade. Tradução Fausto Wolff. 6. ed. São Paulo: Editora Difel, 2004.

Folha de S.Paulo, n. 28.165, ano 86, São Paulo. Domingo, 14 de maio de 2006.

Folha de S.Paulo. n. 28.166, ano 86. São Paulo. Segunda-feira. 15 de maio de 2006.

Folha de S.Paulo. n. 28.171, ano 86, São Paulo. Sábado, 20 de maio de 2006.

Folha de S.Paulo, n. 28.172, ano 86, São Paulo. Domingo, 21 de maio de 2006. 